УДК 327(73:536),1989/1993”

Olesia Pavliuk,

Higher State Educational Institution of Ukraine

"Bukovinian State Medical University"

Chernivtsi (Ukraine),

\section{Олеся ПАВЛЮК,}

ВДНЗ України «Буковинський державний

медичний університет»,

Чернівці (Україна),

o_pokorna@ukr.net
US POLICY IN PERSIAN GULF

DURING GEORG H. W. BUSH

PRESIDENCY

ПОЛІТИКА США ЩОДО РЕГІОНУ

ПЕРСЬКОЇ ЗАТОКИ ПІД ЧАС

АДМІНІСТРАЦЇ̈ ДЖ. БУША-

СТАРШОГО
Ключевые слова: внешняя политика США, Персидский залив, Ирак, Иран, Война в Персидском заливе 1991 г., администрачия Дж. Буша-старшего.
Павлюк О. И. Политика США в отношении региона Персидского залива при администрации Дж. Буша-старшего.

В начале 1990-х гг. международные отношения характеризовались многочисленными изменениями мирового порядка и окончанием длительного противостояния двух сверхдержав. Президент Дж. Бушстарший, который пришел к власти в 1989 г., был вынужден бороться с этими резкими изменениями мироустройства. В регионе Ближнего и Среднего Востока 41-му Президенту США пришлось адаптировать свою внешнюю политику, чтобы она соответствовала новому мировому порядку. Администрация Дж. Буша столкнулась с первым полномасштабным международным кризисом после окончания холодной войны летом 1990 г., когда Ирак вторгся в соседней Кувейт. Другой региональный лидер Исламская Республика Иран была ослаблена политически и экономически, поскольку значительно пострадала после войны 1980-88 гг. Основным вектором внешней политики США на Среднем Востоке, таким образом, было сдерживание попытки Саддама Хусейна укрепить свою роль лидера в регионе, используя противоречия между Ираном и Ираком в Персидском заливе.
George. H. W. Bush assumed the US presidency during the tumultuous global change. The main historic turning point was the end of the Cold War, which for four decades has been the determining factor in international relations. These changes contributed to the development of new US-Soviet and, later, US-Russian relations and also slightly weakened opposition, even if cooperation did not seemed so real.

The end of the Cold War eased tensions in the international system and increased room for maneuver in relations between states and non-state actors. The collapse of the Soviet Union showed the victory of United States in the Cold War, which gave full authority to the 41st president to speak openly about a "New World Order" based on strong international institutions and a high level of cooperation between states. Foreign policy in administration G. Bush played more significant role than domestic, so a strong team of advisers and consultants was assembled, which included Secretary of State J. Baker, National Security Adviser B. Scowcroft, Secretary of Defense D. Cheney, and Chairman of the Joint Chiefs of Staff C. Powell.

US national interests in the Near and Middle East remained relatively constant from 1946 to 1989. The United States pursued three main objectives in the region: containment of the Soviet Union, maintaining the safe existence for Israel and access to oil. The end of the Cold War stopped the confrontation with the Soviet Union. However, the 
strategy of "containment" has carried out further in the region, but the USSR was replaced by such states as Iran and Iraq as the object of deterrence.

In the early 1990's., international relations were characterized by numerous changes in the world order and the end of the long confrontation between the two superpowers. President G. H. W. Bush, who came to power in 1989, was forced to deal with these sharp changes in the system of international relations. In the region of Near and Middle East G. Bush had to adapt his foreign policy to suit the new world order. As the containment of Soviet Union was already unnecessary and Israeli sovereignty was almost guaranteed due to the loss of Soviet influence in the Arab countries of the Middle East, access to oil became the only vulnerable area of US national interests in the region. Thus, American priorities in the Middle East at that time focused on the Palestinian-Israeli peace process and ensuring constant access to Gulf oil.

George. H. W. Bush administration was confronted with the first full-scale international crisis after the Cold War in the summer of 1990 when Iraq invaded neighboring Kuwait. With decreasing threat to the Arab countries of the Middle East by Iran, which suffered greatly after the war 1980-88 Saddam Hussein attempts to strengthen his leadership role in the region have failed. The desire of Iraq to restore its economy after the war with IRI with the help of Gulf countries contrasted with the wishes of the GCC and other small monarchies of the region and faced with indifference on his proposal to establish close relations or political and military cooperation with Baghdad. Then Saddam Hussein decided to expand his cooperation with moderate Arab countries and unite in struggle against Iran, initiated the establishment of the Arab Cooperation Council (CAC) in February 1989, with the participation of North Yemen, Iraq, Jordan and Egypt. CAC was created as a response to the fact that these four countries were not included in the GCC. Iraq also resumed diplomatic relations with Egypt and in March 1989 signed an agreement with Saudi Arabia ${ }^{1}$.

However, Saddam Hussein realized that the fastest way to expand its influence is through diplomacy, and therefore needed the support of the US in the international arena. Consequently, Baghdad tried to maintain close relations with Washington, which got better during the war years 1980-88. ${ }^{2}$

The American presence in the Middle East still was welcomed by the countries of Persian Gulf that after the Iran-Iraq War were afraid for their safety. United States during the administration of G. H.W. Bush, in turn, willingly supported cooperation with the monarchies of the region, as still seen in revolutionary Iran a serious threat to its interests in the Persian Gulf.

Iraq became the main country that was supplying oil to the US and European countries. Furthermore, he represented a large market for exports from Western countries, including grain from US arms and technology from France and Germany. Iraq also had great significance for the maintenance of peace in the Middle East since played an important role in supporting the historic recognition of the Palestine Liberation Organization of Israel's right to exist in November 1988 and supported a peaceful settlement of the Arab-Israeli conflict. While it was widely believed in the international community that Saddam Hussein stepped on a moderate path, though, as the political scientist K. Juster noted, in retrospect it was wishful thinking ${ }^{3}$.

So June 23, 1989 the meeting of the National Security Council was held to discuss issues that concerned the policy on the Persian Gulf and George H. W. Bush has signed 2 October 1989 National Security Directive 26, which stated US foreign policy vectors in the Gulf region ${ }^{4}$.

The Directive stated that access to the oil fields of the Persian Gulf and the security of friendly to US countries in the region are vital to national security and the United States obliged to defend those interests and if necessary to use military force. It also argued that normalization of relations between the United States and Iraq will serve long-term interests and promote stability in the Persian Gulf in particular and in the Middle East in general. Directive empowered the US government on political, economic and other incentives toward Iraq to promote the development of bilateral relations and maintain Saddam Hussein's moderate foreign policy direction. Directive №26 encouraged American companies to take part in the reconstruction of the Iraqi economy, including energy, and proposed to consider the supply to Iraq of non-lethal military aid and medical supplies ${ }^{5}$.

Thus, US Department of Agriculture issued a loan of $\$ 1.05$ billion to Iraq for the purchase of grain and farm machinery, and in June 1989, a large delegation of businessmen from the US gathered in Baghdad which emphasized the high level of cooperation in this area. The State Department was also interested in the continuation of Commodity Credit Cooperation, on which Washington's influence on Baghdad depended because it could promote the peace process in the Middle East and influence the behavior of Iraq, limiting missile proliferation in the region.

However, in 1990 there have been great changes in the foreign policy of Iraq. Once it became known that Iraq redirected American loans aimed to finance 
agricultural goods to finance its military programs, officials began to express deep concern about the credit program ${ }^{6}$.

To limit the armament policy of Iraq the United States not only suspend Commodity Credit Cooperation, forbidding any credits in Iraq, but also developing a campaign to persuade other countries such as France, Germany, USSR, Japan, pay attention to the threat of nuclear, missile, chemical and biological warfare in the region ${ }^{7}$. In particular, European countries decided to confiscate high-tech devices that Iraqi companies acquired before that for its weapons program.

The United States, after Saddam Hussein's threats against Israel and ignoring calls to stop escalating nuclear and chemical weapons, decided to respond decisively, proposing a series of measures that limit economic freedom of Iraq. Congress, along with the general trade embargo and travel ban, also voted for a more severe decline in exports of dual-use technologies and prohibited any assistance to Iraq until it permits the international inspection to examine its military facility. Not surprisingly, the tough US policy on nuclear, chemical and missile arming in Iraq has led to the condemnation of Baghdad even among his Arab supporters, namely, Libya, Palestine and Jordan ${ }^{8}$.

In the summer 1990, the relations between Iraq and Kuwait deteriorated sharply because of the controversy surrounding oil prices and OPEC quotas set for its production. Although August 1, 1990 in Jeddah (Saudi Arabia) began Iraqi-Kuwaiti negotiations, the leaders did not come to any agreement, and August 2 Iraq invaded Kuwait, attaching it on the rights of 19th province.

Iraq's aggression against Kuwait was convicted around the world. August 2 UN Security Council passed resolution 660, which condemned the Iraqi invasion of Kuwait and the economic sanctions against Iraq were imposed August 6, 1990 in accordance with UN Security Council Resolution 661. Following Iraq's invasion of Kuwait, President George. H. W. Bush August 20, 1990 approved the Directive 45, which dislocated forces in the Gulf region to protect Saudi Arabia and other US friendly countries from Iraqi aggression and to ensure the implementation of UN resolutions?. The United States conducted also two military operations January 17, 1991 the military command has suspended defensive mission "Desert Shield" and then started the fighting as part of "Desert Storm", held by coalition troops from 34 countries led by the United States ${ }^{10}$.

At the suggestion of the US November 29, 1990 UNSC by Resolution 678 allowed the use of military force against Iraq to liberate Kuwait. League of Arab States, Western European Union,
NATO, and the Cooperation Council of Arab Gulf States supported the decision to use military force. Until February 1991, Iraqi troops were driven out of Kuwait, and the Iraqi Republican Guard units were completely destroyed.

The war ended in less than two months, and the Bush administration successfully coped with the largest military deployment since the war in Vietnam without suffering major military losses 148 American soldiers were killed during the Gulf War ${ }^{11}$. Gulf War resumed military spirit of the US Army and weakened the negative memories of the Vietnam War. Also promoted approval of "New World Order" as stated George H. W. Bush breaking the alliances of the Cold War and using peaceful unification of the countries against the rogue states ${ }^{12}$. President of the United States successfully led coalition and even made sure that many countries have provided military support (including France, UK, Saudi Arabia and Egypt) and financial support (including Kuwait, Saudi Arabia, Japan and Germany) in the war of 1991.

Realizing the imbalance of power in the region, the United States and the international community defeated Iraq, but deliberately did not destroy its power. As National Security Council staff director in charge of the Middle East R. Haass noted, the administration has calculated that strategically better to leave Iraq strong enough to balance the Iranian influence in the region, however, as administration hoped not strong enough to intimidate or interfere in affairs of its Arab neighbors ${ }^{13}$. Such US strategy gave the rise of the final differences in US-Iranian relations and interests in the region, which further differed even more after the Gulf War.

Also, this was the main reason why Bush administration did not trusted and decided not to help the Shia uprising in southern Iraq, which broke out in March 1991 because Iran was implicated in it. IRI called for Iranian uprising and sent fighters to join the rebels.

According to G. Gause, neutrality of the United States was probably one of the main reasons why the uprising, which broke out among Shiite and Kurdish population, was not successful and failed to remove Saddam Hussein from power ${ }^{14}$. George H. W. Bush and National Security Adviser B. Scowcroft initially stated they do not want any US forces be involved in the instability inside Iraq, as hoping that Saddam Hussein and his regime will be overthrown as a result of popular uprising or coup ${ }^{15}$. Their opinion reflected the US concerns about long-term balance of power in the Gulf.

There were other reasons why the US did not support the rebellion in southern and northern Iraq. As not only American military commanders and coalition army operating in the Gulf, but also the US 
government believed that the regime of Saddam Hussein would fall in short period of time, and therefore US considered that involvement of its troops was unnecessary. Another cause was the desire to withdraw US troops from the Persian Gulf to stabilize the region and not shake relations in the Middle East. In addition, one more factor played an important role: international pressure from China, the Soviet Union, and Turkey and other countries in the Gulf region, such as Jordan, Syria, Egypt and Saudi Arabia, which opposed the creation of the Kurdish state ${ }^{16}$.

However, Washington has decided not to support the Iraqi intifada mainly because he was afraid that Iran become the main country that will receive the greatest benefits from the revolution in Iraq. The intentions of President George H. W. Bush were quite pragmatic and lay in to leave Baghdad strong enough to be able to resist Iran. After all, Iranians remained hostile to the United States from the time of the Iran-Iraq war, when the United States suddenly sided with Iraq to prevent Iranian domination in the Gulf region.

Several factors influenced the US-Iranian relations after the Gulf War in 1991. First, as already noted, was the refusal of the USA to support the Shia uprising in Iraq and affect the removal of Saddam Hussein from power, because the United States did not intend to risk and excessively weaken Baghdad because it supposed to be strong enough to counter Iran in the region. This became the "practical purpose" of the US, as C. Powell noted ${ }^{17}$.

Another factor was that George H. W. Bush was convinced that the tensions in the Gulf, which included the US-Iranian relations, should be viewed more broadly than just a regional problem. The President held extensive consultations on the issue, even within the government meeting. This reflected the efforts of George H. W. Bush to value events globally and associated with the intention of Secretary of State G. Baker to distance from the personnel of department, which was in charge of cooperation with Saddam Hussein ${ }^{18}$.

As officials from the State Department noted, the President considered the relationship in the Gulf not like the traditional Middle East crisis but like the first conflict in the post-bipolar world, that is why, in his opinion, its solution required new thinking and new approaches ${ }^{19}$.

In order to sound out the possible prospects of postwar cooperation and economic collaboration George H. W. Bush has sent Secretary of State J. Baker in March with visit to the Middle East countries $^{20}$. Within the visit, the administration had prepared a new attempt to resolve the Arab-Israeli conflict in Madrid in autumn 1991 with the hope of cooperation and opportunities of New World Order.
The third important factor was the conclusions that have made for themselves Gulf countries and IRI after the Iran-Iraq war. While the Arab countries of the Middle East have confirmed their desire and need for protection from external forces, namely the United States, Iran has made almost the opposite conclusion. The Islamic Republic saw in such cooperation a major threat to its own ambitions and influence on policy in the region ${ }^{21}$. Therefore, Iran resumed relations with Saudi Arabia, and enhanced its cooperation with several Gulf States, including Bahrain, Oman, UAE and Yemen.

However, establishing relations with neighboring countries did not have any result. Mutual mistrust and conflicting intentions of regional players made it impossible to negotiate successfully on a joint collective security in the region, and once again undermined ambitions of Iran and once again convinced it to blame the US desire to influence the affairs of the Gulf ${ }^{22}$. However, the failure to cooperate on regional security was partially offset by success in the economic sphere. In May 1991, Iranian leaders have proclaimed by loud statement that the government is open to investment and cooperation with the business (particularly European) and returns to the world economic community. Iran's economy was in very bad condition, in 1990 GDP per capita fell by $42 \%$ than in 1977, and state funding for such areas as health, education and housing fell by half ${ }^{23}$.

Considering that Iran's efforts to improve relations with the rest of the world were primarily motivated by economic decline, Deputy Foreign Minister A. Maleki persuaded of the need to continue improving relations with the US, arguing that it may take 10 years before Iran will master all other existing markets. He offered to welcome commercial ties between the countries, but not to develop relations to a greater level or in other areas. ${ }^{24}$.

The last factor was that the Gulf War did not change the George H.W. Bush belief that the hostages remain a major sticking point in US-Iranian relations. The sudden invasion of Kuwait by Iraq, though not immediately, but gave impetus to resolve this problem. As the scientist D. Murray noted, a number of factors contributed to curb the crisis of hostages: the weakening of Iraq and the prospect of new geopolitical opportunities; H. Rafsanjani's efforts to implement economic reforms and to a lesser extent, to convince the international community that Iran serves as a reliable, stable, focused on a diplomatic solution to the conflicts player; fear that the US will seek to nullify all the efforts of Iran; and finally, the influence of Tehran on Lebanese terrorists ${ }^{25}$. 
After all the hostages were liberated, George $\mathrm{H}$. W. Bush decided to go to a certain rapprochement with Iran. The proof of such policy was the fact that in September 1991, Secretary of State J. Baker said Perez de Cuellar that the US is ready to restore diplomatic relations with Iran, and were willing to meet Iranian Foreign Minister H. Velayati in New York $^{26}$. National Security Council officials on Middle East issues B. Riedel was even ordered to develop a document with the main options for establishing negotiations ${ }^{27}$.

However, some circumstances prevent rapprochement between the two countries. Several assassinations, including former Prime Minister S. Bakhtiar in August 1991 and growing tensions between Iran and neighboring countries in the Gulf confirmed that Tehran is not going to change the vector of its radical foreign policy ${ }^{28}$.

Moreover, it was reported that Iran seeks to improve its nuclear program and attempts to create nuclear weapons. Although after the revolution in 1979 Iran suspended its nuclear program because of radically negative attitude to nuclear energy by its new leader, Ayatollah Khomeini, but devastating Iran-Iraq war of 1980-1988, confrontation with the US and a growing number of facts about a secret Iraqi nuclear weapons program largely prompted Ayatollah Khomeini to restore Iran's nuclear program. IAEA reports in 2009 showed that in April 1984, the President Khamenei declared that Ayatollah Khomeini decided to resume nuclear program as the only way of ensuring the collapse of the Islamic revolution from its enemies, especially the United States and Israel ${ }^{29}$.

While the US often introduce economic sanctions against hostile countries, but foreign policy towards Iraq in the late 1980s was an exception. From August 1988 to August 1990 - the period between the end of the Iran-Iraq war and Iraq's invasion of Kuwait - US sought to "engage" Iraq to moderate its behavior and build bilateral relations. During this period, Washington kept trade relations with Iraq and gave credit for the supply of agricultural products.

Discussions about finding the best strategies to deal with recalcitrant regimes and the relative advantages of containment strategies against the policy of engagement were conducted since the early 1980s after the debate on the implementation of Reagan administration policy of "constructive engagement" toward South Africa. Although engagement strategies were much less applied in US foreign policy because of the popularity of punitive methods - such as sanctions and military force, they emphasize the need to identify the most favorable circumstances, the use of incentives or rewards for the formation of rough state behavior ${ }^{30}$.
Although, according to some scientists, including K. Juster, US foreign policy of partial "engagement" toward Iraq was not successful, researchers of the Brookings Institution R. Haass and M. O'Sullivan argued that engagement strategy, not being very successful during application may ultimately contribute while involving the assistance of other countries and their aid as in the military confrontation and in the application of sanctions ${ }^{31}$. The situation with Iraq showed it the best, because namely such foreign policy toward Baghdad before the Gulf War has helped the US to mobilize a large international coalition and prevent the claims of Arab countries that the invasion of Kuwait by Iraq was made in response to pressure from the United States.

Nevertheless, the result was not so unambiguous. As noted by $\mathrm{Z}$. Brzezinski the response of G. H.W. Bush on Iraq's aggression against Kuwait showed his greatest military victory, and the most unconvincing political result ${ }^{32}$. The decision to go with war against Baghdad, to achieve the desired result by force, eventually became a crucial test of character and leadership of George. H.W. Bush. According to the author of Second Chance, geostrategic implications of personal triumph proved more problematic, because although Saddam Hussein was defeated and humiliated, he stayed in power, and the region continued to suffer from instability and disputes, including the ShiiteSunni confrontation. George H. W. Bush in monograph World Transformed, written with National Security Advisor B. Scowcroft, convinced that the prosecution of Saddam Hussein in Iraq and attempts to overthrow his government would then lead to the destabilization of the region and to the long military resistance ${ }^{33}$.

Anglo-American coalition has created an opportunity for the US to use its special status in the Middle East to address the fiercest conflict in the region, which has caused many hardships and became the main source of growing anti-American disposition, and namely the Israeli-Palestinian conflict. March 6, 1991 President George H. W. Bush made an official statement, declaring its intention to achieve a profound peace agreement between Israel and its neighbors. And by the end of 1991 Peace Conference was organized jointly with the Soviet Union in the Madrid, which took place on October 30 with the participation of Israel, Syria, Jordan, Lebanon and the PLO. However, the parties have not reached the common plan to solve the problem despite the strong statement of George H. W. Bush in March 1991.

George. W. Bush had more advantage to achieve a breakthrough in the peaceful settlement of the Arab-Israeli conflict, according to Z. Brzezinski 
than any other US president since the days of Eisenhower Administration. Nevertheless, he did not use the great prestige of the United States at that time in the region to press on the parties of the conflict and to establish specific principles of the key contentious issues of confrontation in the Middle East ${ }^{34}$. However, the biggest drawback of Bush presidency was that, although it was difficult to justify the actions of the United States without a clear national interest, but declaring a new approach in US foreign policy, he was not able to realize the promising New World Order and take greater role as a world leader at the end of the Cold War to protect democratic regimes and human rights improvement.

\section{ЛІТЕРАТУРА}

${ }^{1}$ Ryan C. Jordan and the Rise and Fall of the Arab Cooperation Council / C. Ryan // Middle East Journal. - 1998. - Vol. 52, No. 3. - pp. 386-401.

${ }^{2}$ Gause G. The International Relations of the Persian Gulf / G. Gause. - Cambridge: Cambridge University Press, 2010. - p. 89.

${ }^{3}$ Juster K. The United States and Iraq: Perils of Engagement / K. Juster // Honey and Vinegar: Incentives, Sanctions, and Foreign Policy / edt. R. Haass, M. O'Sullivan. - Brookings Institution Press, 2000. - p.55.

${ }^{4}$ Davis R. U.S. Foreign Policy and National Security [2 volumes]: Chronology and Index for the 20th / R. Davis. - Praeger, 2010. - p. 699

5 National Security Directive 26. The White House, Washington, October 2, 1989. - Режим доступу: http://fas.org/irp/offdocs/nsd/nsd26.pdf

${ }^{6}$ Under Secretary of State for Political Affairs Robert Kimmitt to the Secretary, Note: DC Meeting on Iraq, April 17, 1990 // The Middle East and the United States: History, Politics, and Ideologies / ed. D. Lesch. - Westview Press, 2011. - p. 360.

${ }^{7}$ Baram A. US Input into Iraqi Decisionmaking, 1988-1990/ A. Baram // The Middle East and the United States: History, Politics, and Ideologies / ed. D. Lesch. - Westview Press, 2011. - p. 361.

${ }^{8}$ Baram A. US Input into Iraqi Decisionmaking, 1988-1990 / A. Baram // The Middle East and the United States: History, Politics, and Ideologies / ed. D. Lesch. - Westview Press, 2011. - p. 363

9 National Security Directive 26. The White House, Washington, October 2, 1989. - Режим доступу: http://fas.org/irp/offdocs/nsd/nsd26.pdf

${ }^{10}$ Knights M. Cradle of Conflict: Iraq and the Birth of Modern U.S. Military Power / M. Knights. United States Naval Institute, 2011. - p. 20
${ }^{11}$ George H W. Bush: Foreign Affairs, Miller Centre. - Режим доступу: http://millercenter.org/ president/bush/essays/biography/5

${ }^{12}$ George Bush: Address Before a Joint Session of the Congress on the State of the Union, January 31, 1990 / Public Papers of the Presidents. - Режим доступу: http://www.presidency.ucsb.edu/ ws/?pid $=18095$

13 Haass R. The George H. W. Bush Administration / R. Haass // Iran Primer: Power, Politics, and U.S. Policy / ed. R. Wright. - United States Institute of Peace, 2010. - p. 138

${ }_{14}$ Gause G. The International Relations of the Persian Gulf / Gregory Gause. - Cambridge University Press, 2009. - p. 118.

${ }^{15}$ Bush G., Scowcroft B. A World transformed / G. Bush, B. Scowcroft. - Vintage, 1999. - p. 459.

16 Gause G. The International Relations of the Persian Gulf / Gregory Gause. - Cambridge University Press, 2009. p. 117-119.

${ }^{17}$ Powell C., Persico J. My American Journey / C. Powell, E. Joseph Persico. - Ballantine Books, 2003. - p. 531

${ }^{18}$ Murray D. US Foreign Policy and Iran: AmericanIranian Relations since the Islamic Revolution / D. Murray. - Routlege, 2009. - p.82

19 Goshko J. Bush Seen Seeking Little Advicefrom US Experts on Arab World / John M. Goshko // Washington Post, November 1990. Режим доступу: http://www.highbeam.com/doc/ 1P2-1160486.html(accessed 10.04.2015).

${ }^{20}$ Hoffman D. Middle East Unstable as Ever / D. Hoffman // Washngton Post. - 1991. - Режим доступу: http://www.wrmea.org/1991-februry-mar $\mathrm{ch} /$ middle-east-unstable-as-ever.html

${ }^{21}$ Chubin S. Iran and Regional Security / Shahram Chubin // Survival. - vol.34, no.3. - 1992. - p.73

${ }^{22}$ Murray D. US Foreign Policy and Iran: American-Iranian Relations since the Islamic Revolution / D. Murray. - Routlege, 2009. - p.84

${ }^{23}$ Iran's Economy: A Survey of Its Decline, 1 August 1991, СIA. - Режим доступу: http://www. foia.cia.gov/sites/default/files/document_conversion s/89801/DOC_0000266047.pdf

${ }^{24}$ Lippman T. Iranians May Welcome Americans but not Relations with US / Thomas W Lippman // Washington Post. - 8 June 1991. - Режим доступу: http://www.washingtonpost.com/wp-srv /inatl/longterm/archive/post012991_2.htm

25 Murray D. US Foreign Policy and Iran: American-Iranian Relations since the Islamic Revolution / D. Murray. - Routlege, 2009. - p.83

${ }^{26}$ Picco G. Man Without a Gun : One Diplomat's Secret Struggle to Free the Hostages, Fight 
Terrorism, and End a War / Giandomenico Picco. Crown, 1999. - p.196.

${ }^{27}$ Slavin B. Bitter Friends, Bosom Enemies: Iran, the U.S., and the Twisted Path to Confrontation / Barbara Slavin. - NY: St. Martin's Griffin, 2009. p.181.

28 Ehteshami A. After Khomeini: The Iranian Second Republic/ Anoushiravan Ehteshami, Routledge, 1995. - p. 154

${ }^{29}$ Albright D. Iran's Nuclear Program / D. Albright // Iran Primer: Power, Politics, and U.S. Policy / ed. R. Wright. - United States Institute of Peace, 2010.

30 George A. Bridging the Gap: Theory and Practice in Foreign Policy / Alexander L. George.

- Washington DC: United States Institute of Peace Press, 1993.

${ }^{31}$ Haass R. Terms of Engagement: Alternatives to Punitive Policies / R. Haass, Meghan L. O'Sullivan // Surviva, 2000. - vol., 42, no. 2. - p. 4.

${ }^{32}$ Brzezinski Z. Second Chance: Three Presidents and the Crisis of American Superpower / Z. Brzezinski. - NY: Basic Books, 2007. - p. 72

${ }^{33}$ Bush G., Scowcroft B. A World transformed / G. Bush, B. Scowcroft. - Vintage, 1999. - p. 463.

${ }^{34}$ Brzezinski Z. Second Chance: Three Presidents and the Crisis of American Superpower / Z. Brzezinski. - NY: Basic Books, 2007. - p. 77

\section{Павлюк О. І. ПОЛІТИКА США ЩОДО РЕГІОНУ ПЕРСЬКОЇ ЗАТОКИ ПІД ЧАС АДМІНІСТРАЦІЇ ДЖ. БУША-СТАРШОГО}

На початку 1990-х рр. міжнародні відносини характеризувались численними змінами світового порядку та закінченням довготривалого протистояння двох наддержав. Президент Дж. Бушстарший, який прийшов до влади в 1989 р., був змушений боротися 3 цими різкими змінами світоустрою. У регіоні Близького та Середнього Сходу 41-му Президенту США довелося адаптувати свою зовнішню політику, щоб вона відповідала новому світовому порядку. Американська присутність на Середньому Сході дуже віталась монархіями регіону, які після Ірано-іракської війни побоювались за свою безпеку. Сполучені Штати за адміністрації Дж. Буша-старшого, в свою чергу, охоче підтримували співпрацю з монархіями регіону, оскільки як і раніше вбачали в революційному Ірані серйозну загрозу для своїх інтересів в Перській затоці.

Основною країною постачання нафти в США та західні країни став Ірак. Крім того він представляв великий ринок для експорту західних країн, зокрема зерна з США, озброєння та техніки з Франції та Німеччини. Ірак також мав велике значення для підтримання миру на
Близькому і Середньому Сході, оскільки відіграв важливу роль у підтримці історичного визнання Організацією визволення Палестини права Ізраїлю на існування в листопаді 1988 р. та підтримав мирне врегулювання арабо-ізраїльського конфлікту. В той час серед міжнародного співтовариства широко була поширена думка, що С. Хусейн став на більш поміркований шлях, хоча, в ретроспективі це було прийняття бажаного за дійсне.

Аміністрація Дж. Буша зіткнулась 3 першою повномасштабною міжнародною кризою після закінчення холодної війни влітку 1990 р., коли Ірак вторгся у сусідній Кувейт. Інший регіональний лідер - Ісламська Республіка Іран була слабка, оскільки значно постраждала після війни 1980-88 pр. Основним вектором зовнішньої політики США на Середньому сході, таким чином, було стримування намагання С. Хусейна зміцнити свою роль лідера в регіоні, використовуючи протистояння між Іраном та Іраком у Перській затоці.

Ключові слова: зовнішня політика США, Перська затока, Ірак, Іран, Війна у Перській затойі 1991 р., адміністраиія Дж. Бушастариого.

Received 21-09-2015

Advance Acces Publischer: November 2015 